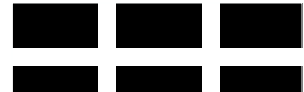 \\ THE WILLIAM DAVIDSON INSTITUTE AT THE UNIVERSITY OF MICHIGAN
}

\section{Inflation Differentials in EU New Member States: An Empirical Evidence}

By: Roman Horvath and Kamila Koprnicka

William Davidson Institute Working Paper Number 937

October 2008 


\title{
Inflation Differentials in EU New Member States: An Empirical Evidence
}

\author{
Roman Horváth* \\ Czech National Bank \\ and Institute of Economic Studies, Charles University, Prague \\ Kamila Koprnická \\ Czech National Bank \\ and Institute of Economic Studies, Charles University, Prague
}

\begin{abstract}
In this paper, we examine the determinants of inflation differentials in a panel of the new European Union member states vis-à-vis the euro area in 1997-2007. Our main results are as follows. Exchange rate appreciation and higher price level in the new EU members is associated with narrower inflation differential vis-à-vis the euro area, while fiscal deficit and positive output gap seem to contribute to higher inflation differential. Nevertheless, the effect of price convergence on inflation differentials is found to be dominating in these countries suggesting that a country with price level $20 \%$ below the euro area average is likely to exhibit inflation nearly one percentage point above the euro area. Overall, our results indicate that real convergence factors rather than cyclical variation are more important for inflation developments in the new EU members, as compared to the euro area.
\end{abstract}

JEL Classification: E31, F41

Keywords: inflation differentials, price convergence, exchange rate, New EU members, panel data

* We thank anonymous referee, Kateřina Šmídková and seminar participants at the Czech National Bank and Charles University for helpful comments. The views expressed in this paper are not necessarily those of the Czech National Bank.

Corresponding author: roman.horvath@,cnb.cz and roman.horvath@gmail.com 


\section{Introduction}

After the EU enlargement in 2004 and 2007, 12 new countries became members of the Economic and Monetary Union with derogation on the euro introduction. One of the preconditions for successful euro adoption in these countries is to sustain low inflation vis-à-vis their euro area counterparts. This is also stipulated in the inflation criterion of the Maastricht treaty, which is defined relative to the inflation performance of other EU countries. Therefore, it is of great interest to understand which factors contribute to the inflation differentials in these countries (ECB, 1999; ECB, 2003). ${ }^{1}$

As the EU new member states (NMS) are catching-up, they typically exhibit real exchange rate appreciation (Égert et al., 2006). In many countries with floating exchange rate regime, real exchange rate appreciation materializes mainly through nominal exchange rate appreciation contributing to low inflation. Many observers however fear that once these countries adopt euro, which eliminates the possibility of further nominal exchange rate appreciation, they will exhibit higher inflation that will be harmful to country's macroeconomic stability. In fact, this argument seems to become one of the main economic arguments against the early euro adoption. In this paper, we therefore want to investigate which factors influence inflation differentials in the NMS. More specifically, we are interested to contribution of nominal exchange rate appreciation and price convergence (as these countries typically have much lower price level than in the euro area) as well as to a contribution of cyclical factors.

Anticipating our results, we find that both structural and cyclical factors are important determinants of the inflation differentials in the NMS. However, in terms of their relative contribution, the effect of price convergence seems to dominate. All in all, it can be expected that higher inflation rates will be exhibited primarily in catching-up countries that adopt euro with low price level.

The paper is organized as follows. Section 2 provides a brief literature survey. Section 3 presents our empirical model. Section 4 gives the results. Concluding remarks follow.

\footnotetext{
1 According to Fendel and Frenkel (2008), the monetary policy of the European Central Bank took inflation differentials into account in order to avoid deflation in countries such as Germany.
} 


\section{Related Literature}

Various New Keynesian models have been used to analyse the inflation differentials in the euro area. One of such models for the euro area economies is put forward by Hofmann and Remsperger (2005). Their empirical analysis of inflation differentials is carried out by panel generalised method of moments over the period 1999Q1-2004Q2. Their results suggest that the observed inflation differentials are mainly influenced by differences in cyclical positions and fluctuations of the effective exchange rate combined with a rather high level of inflation persistence, while the proxies of price level convergence does not come out significantly. Hofmann and Remsperger (2005) also find that the degree of inflation persistence depend on the past monetary policy regime and expectations. Their results indicate that countries with a history of low and stable inflation rates exhibit zero persistence, while the persistence is rather high otherwise. Given this finding, authors conclude that the monetary policy of the Eurosystem geared at delivering and maintaining low and stable inflation rates in the euro area should reduce inflation persistence in the future.

Analogously to the aforementioned study, Angeloni and Ehrmann (2007) propose a stylised 12-country model of the euro area represented by aggregate demand and aggregate supply equations and use it to analyse the inflation and output differentials observed across the euro area over the period 1998Q1-2003Q2. Angeloni and Ehrmann (2007) point out that the main source of differentials in the early years of the euro area have been aggregate demand or potential output shocks, followed by domestic cost-push disturbances, while euro exchange rate shocks come only third. Moreover, the authors emphasize that inflation persistence have played a central role in amplifying and perpetuating inflation differentials within the monetary union. They claim that for plausible parameter values even small changes in persistence can produce a dramatic changes in the inflation differentials. The paper also concludes that a tight control of average area-wide inflation around a target tends to reduce the differentials.

The long-run determinants of inflation differentials in the euro area are examined by Altissimo et al. (2005). In first part of their study, the authors analyze evidence on the statistical features of observed dispersion in headline inflation rates as well as changes in the components of the consumer price indexes in the euro area. Their findings suggest that most of dispersion in European inflation occurs in the services category of the EU's harmonized consumer prices. In the second part of the study, authors build a dynamic factor model to investigate the sources of dispersion in sector-based measures of dispersion in, on the one hand, a common component 
driven by common factors, and on the other hand, an idiosyncratic component. Altissimo et al. (2005) conclude that their outcomes are in contrast with the supposition that real exchange rate is primarily driven by regionally asymmetric productivity shocks in the traded sector. Indeed, they point instead to relative variations in productivity in the non-traded sector as the main cause of price and inflation differentials, with shocks to productivity in the traded sector being largely absorbed by movements in the terms of trade in the regional economies.

Honohan and Lane (2003) estimate the panel data model to assess the driving factors of inflation differentials in the euro area over the period 1999-2001. More specifically, they examine the relative influence of the country's external exposure, the cyclical position, the fiscal policy, and the price level convergence. Their results suggest that all aforementioned variables belong to vital determinants of inflation differentials in the euro area.

An empirical investigation of inflation differentials in the NMS is rather scant. The existing literature largely focuses on the price convergence and its determinants (Čihák and Holub, 2005, Égert, 2007, Égert, 2008). Égert et al. (2003) and Égert (2007) provide a detailed overview of real convergence, price convergence and inflation differentials in Europe and also analyzes the determinants of inflation differentials in the NMS. It is put forward that Balassa-Samuelson effect is unlikely to explain the observed inflation differentials and that the effect of exchange rate on inflation is weakening over time in Central and Eastern European countries. Stavrev (2006) utilizes dynamic factor model to study the driving forces of inflation in the Central and Eastern European countries that recently became the members of the EU and finds that inflation in these countries is largely driven by common factors.

\section{Empirical Methodology}

We analyze the determinants of inflation differentials in the following NMS: Bulgaria, Cyprus, the Czech Republic, Estonia, Hungary, Latvia, Lithuania, Malta, Poland, Romania, Slovakia, and Slovenia. The source of our data is Eurostat. Our sample period is 1997-2007².

As concerns our empirical methodology, we largely follow Honohan and Lane (2003) who focus their attention to finding the relationship between inflation differentials and the role of exchange

\footnotetext{
2 Due to end-point bias in the HP filter that we use for construction of output gap, we exclude the year 2007 in the following regression analysis. Inflation is based on harmonized index of consumer prices and price level is measured by the Eurostat's comparative price level indicator. Next, we also use nominal effective exchange rate in the empirical analysis. The source of our data is Eurostat.
} 
rate channel, output gap (we estimate the gap using HP filter on the log of GDP), fiscal policy, and the countries' relative price level. Honohan and Lane's study (2003) investigate the role of above mentioned relations in a panel of euro area countries using annual data over 1999-2001. In contrast to Honohan and Lane (2003), our time coverage is longer and therefore, we are likely to evaluate the role of structural factors such as price convergence in a fuller manner.

Honohan and Lane (2003) start the analysis with a fairly general specification for inflation differentials that can be postulated as

$$
\pi_{i t}-\pi_{t}^{E}=\beta\left(z_{i t}-z_{t}^{E}\right)+\delta\left(\left[P_{i t-1}-P_{i t-1}^{*}\right]-\left[P_{t-1}^{E}-P_{t-1}^{E^{*}}\right]\right)+\varepsilon_{i t}
$$

where $\pi_{i t}$ and $\pi_{t}^{E}$ are the annual national and euro zone inflation rates, respectively; $z_{i t}$ and $z_{t}^{E}$ denote national and euro area variables that exercise short-term influence on the inflation rate; $P_{i t}$ and $P_{t}^{E}$ denote the national and euro area price levels and $P_{i t}^{*}$ and $P_{t}^{E *}$ represent the national and euro zone long-run equilibrium price levels.

For a convergence club such as the euro area with rather tight trade and institutional linkages likely eliminating income and productivity differentials over time, Honohan and Lane (2003) assume a common long-run national and euro area price level. ${ }^{3}$ The assumption of a common long-run price level allows simplifying (1) into

$$
\pi_{i t}-\pi_{t}^{E}=\beta\left(z_{i t}-z_{t}^{E}\right)+\delta\left(P_{i t-1}-P_{t-1}^{E}\right)+\varepsilon_{i t}
$$

It is easy to realize that a combination of euro area variables results in a time dummy. Hence, we can write

$$
\pi_{i t}=\phi_{t}+\beta z_{i t}+\delta P_{i t-1}+\varepsilon_{i t}
$$

We define the vector $z$ in line with Honohan and Lane (2003) to allow the comparison of our results to the previous research, i.e. $z=\left[\Delta N E E R_{i t-1}, G A P_{i t}, F I S C_{i t}\right]$, where $\triangle N E E R_{i t-1}$ is the

\footnotetext{
${ }^{3}$ Honohan and Lane (2003) also experiment with the alternative hypotheses that long-run price levels may diverge due to productivity or income differences; however, they failed to find a significant role for these hypotheses.
} 
lagged change of nominal effective exchange rate, GAP ${ }_{i t}$ denotes the output gap, FISC $C_{i t}$ represent the fiscal deficit and $P_{i t-1}$ is the lagged price level. This gives us the following empirical specification:

$$
\pi_{i t}=\phi_{t}+\beta_{1} \Delta N E E R_{i t-1}+\beta_{2} G A P_{i t}+\beta_{3} F_{S S C}+\delta P_{i t-1}+\varepsilon_{i t}
$$

Note that the time dummies $\left(\phi_{t}\right)$ in (4) capture the common movements in inflation, so that the regression explains the inflation differentials in terms of idiosyncratic national movements. The coefficient on effective exchange rate $\left(\beta_{1}\right)$ is expected to be negative, as exchange rate appreciation decreases inflation rate. On the other hand, $\beta_{2}$ is expected to be positive, as higher output gap results in more inflationary environment. $\beta_{3}$ is likely to be negative, as fiscal surplus reduces aggregate demand and therefore contributes to lower inflation. The sign of $\delta$ is expected to be negative as lower price level is likely to be associated with higher inflation rate. Obviously, output gap and fiscal balance can be endogenous to inflation and therefore, we estimate (4) by the generalized method of moments (GMM), where we instrument endogenous variables by their lagged values.

We present the results based both on annual and quarterly frequency of data. Clearly, the advantage of quarterly data lies in greater degrees of freedom, but on the other hand, as price level and fiscal deficit are available only yearly for these countries, we had to interpolate these two variables (by the quadratic match procedure; note that the different interpolation techniques had rather little effect on the results). As some data are interpolated, we make sure that our instruments are sufficiently lagged to address the endogeneity issue appropriately.

\section{Results}

In this section, we first characterize the inflation developments in the NMSs and second, we provide regression results on the determinants of inflation differentials.

\subsection{Inflation Characteristics}

Over our sample period 1997-2007, inflation rates in the NMS were often close to double-digit level (unweighted average in our sample is 7.7 year-on-year inflation rate), but substantial differences among countries in terms of their inflation performance exist, too. The lowest inflation rates were observed in Malta and Cyprus (2.6\% for both countries), i.e. the countries that did not undergo the transition from central planning to market-oriented economy and the 
highest in Hungary and Romania (8.5\% and 35\%, respectively). All countries display positive inflation differential vis-à-vis the euro area on average during our sample period, as reported in Table 1.

Table 1 - Inflation Differentials in the NMS Relative to the Euro Area, 1997-2007

\begin{tabular}{lclc}
\hline Country & $\begin{array}{c}\text { Inflation } \\
\text { differential }\end{array}$ & Country & $\begin{array}{c}\text { Inflation } \\
\text { differential }\end{array}$ \\
\hline Bulgaria & 5.44 & Lithuania & 1.01 \\
Cyprus & 0.65 & Malta & 0.63 \\
Czech Rep. & 1.55 & Poland & 3.65 \\
Estonia & 2.95 & Romania & 35.34 \\
Hungary & 6.58 & Slovak Rep. & 4.49 \\
Latvia & 2.98 & Slovenia & 4.00 \\
\hline
\end{tabular}

Note: Inflation rate is based on Harmonized Index of Consumer Prices (y-o-y growth rate, annual data); unweighted average of annual inflation differentials in period 1997 - 2007; in percentage points.

Source: Author's calculations based on Eurostat data.

Despite the NMS exhibit on average higher inflation than in the euro area, there is some country heterogeneity. In general, we can observe three main patterns of inflation developments over time in these countries, as presented in Figure 1-3. In Figure 1, we put together countries that experienced relatively stable inflation differentials, which fluctuated around the euro area mean inflation for most of the time (i.e. Cyprus, the Czech Republic and Malta). The U-shaped development in inflation differentials is characteristic for the Baltic countries, that disinflated substantially over the 1990s, but whose inflation rates later have surged up again (see Figure 2). The third group (i.e. Bulgaria, Hungary, Poland, Romania, Slovakia and Slovenia) can be labelled as group of formerly relatively high inflation countries that have, however, underwent relatively successful process of disinflation recently. 


\section{Figure 1 - Inflation Differentials in the NMS, Low Inflation Group}

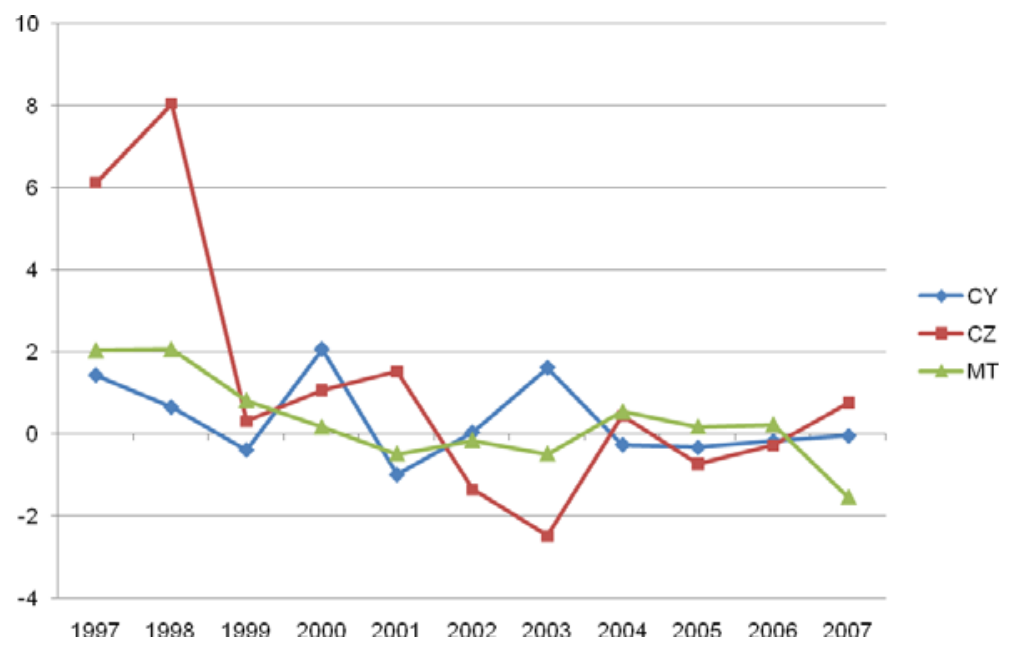

Note: Inflation rate is based on Harmonized Index of Consumer Prices (y-O-y growth rate, annual data); in percentage points; period 1997 - 2007; CY - Cyprus, CZ - Czech Republic, MT - Malta.

Source: Author's calculations based on Eurostat data.

Figure 2 - Inflation Differentials in the NMS, Baltic Group

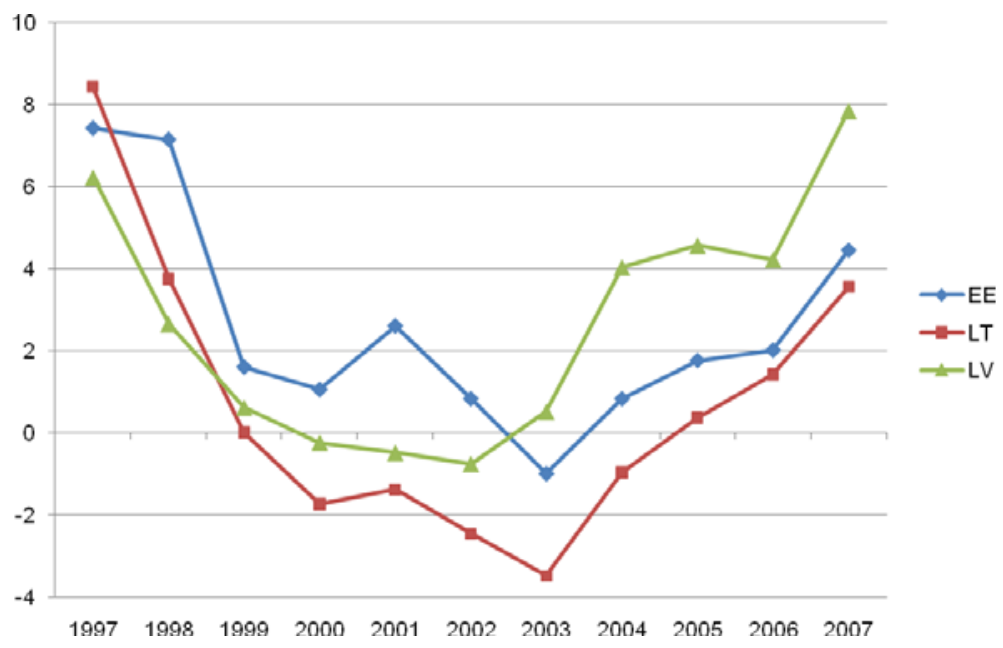

Note: Inflation rate is based on Harmonized Index of Consumer Prices (y-o-y growth rate, annual data); in percentage points; period 1997 - 2007; EE - Estonia, LT - Lithuania, LV - Latvia.

Source: Author's calculations based on Eurostat data. 
Figure 3 - Inflation Differentials in the NMS, High Inflation Group

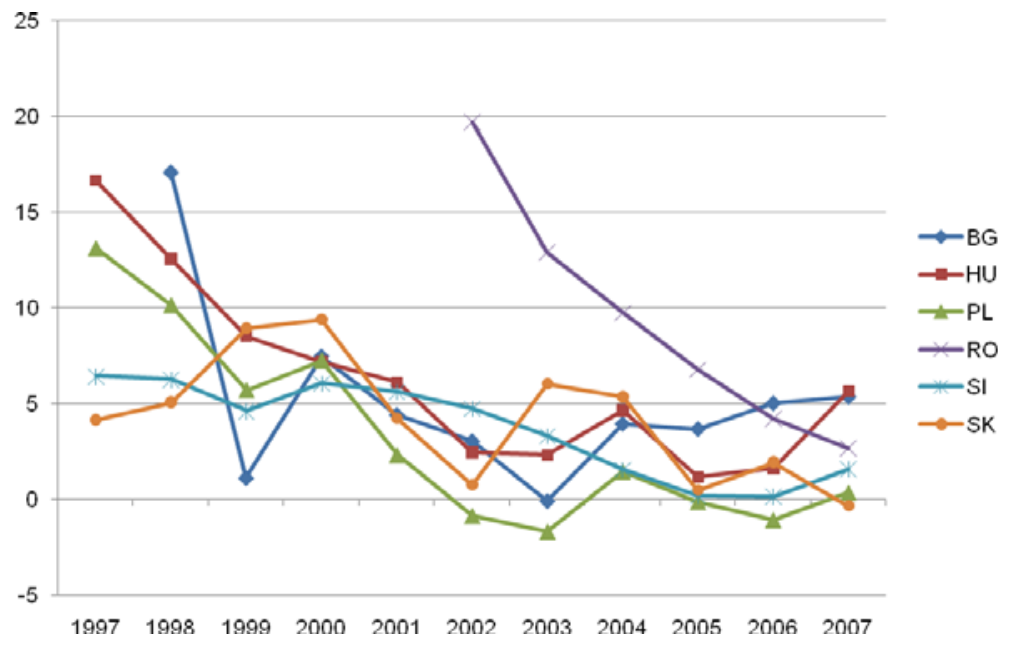

Note: Inflation rate is based on Harmonized Index of Consumer Prices (y-o-y growth rate, annual data); in percentage points; period 1997 - 2007; BG - Bulgaria, HU - Hungary, PL - Poland, RO - Romania, SI - Slovenia, SK - Slovakia. The inflation differential in Romania is too high before 2002 and is not reported.

Source: Author's calculations based on Eurostat data.

Next, we present scatter plots with kernel fit to assess informally how inflation differentials in these countries are linked to various macroeconomic fundamentals. Figure 4 gives the results. We can see that nominal effective exchange rate appreciation is associated with lower inflation. Similarly, higher price level typically goes in hand with lower inflation. Next, cyclical conditions seem to contribute to inflation, too. Positive output gap and fiscal deficit seem to be associated with higher inflation. However, it is also clear from the data that there are some outliers in terms of inflation record. More specifically, Romania has exhibited very high inflation rates at the beginning of our sample (sometimes even more than 100\%). As a result, we carry out sensitivity checks by excluding Romania from our regression analysis in the following section. 
Figure 4 - Inflation and Macroeconomic Fundamentals

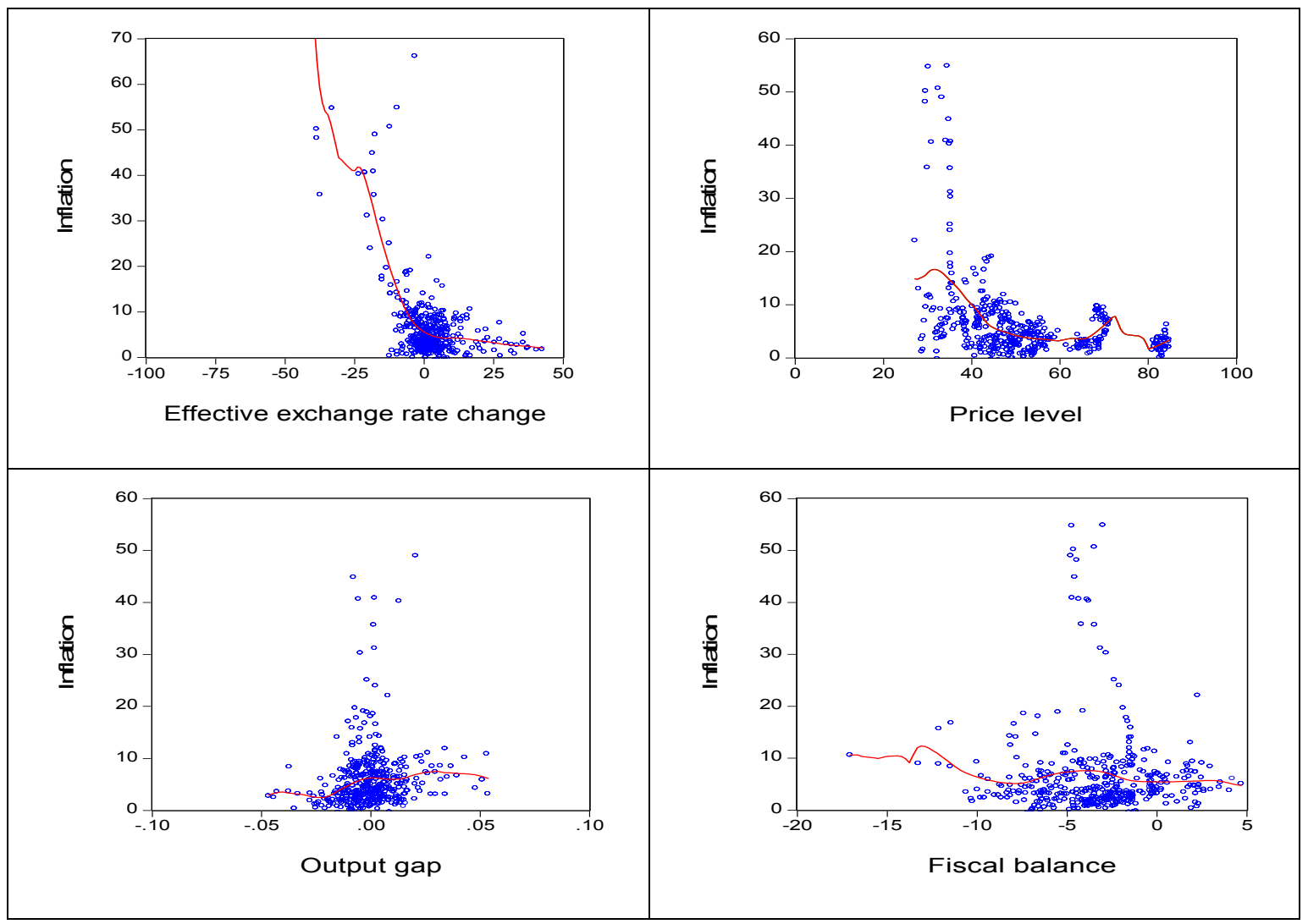

Source: Author's calculations based on Eurostat data.

\subsection{Regression Analysis}

Here we provide our estimation results on the determinants of inflation differentials in the NMS.

Table 2 reports the results for all countries. Column (1)-(6) contains our results, while (7) presents the attendant results of Honohan and Lane (2003) for the euro area. We present various specifications to shed light on the robustness of results.

The results in Table 2 indicate that nominal effective exchange rate appreciation in the NMS reduces the inflation differentials. This result is robust to different frequency of data, different sample period and different lag of exchange rate (one vs. four quarters). Output gap exerts positive influence on inflation, albeit in many cases the standard errors are larger (especially with yearly frequency of data). ${ }^{4} \mathrm{Next}$, the sign of fiscal surplus' coefficient is correct, but in most cases insignificant. Countries with lower price level are found to exhibit higher inflation.

\footnotetext{
${ }^{4}$ See Fidrmuc and Korhonen (2006) on synchronization of cyclical conditions in the NMS. We also used the output gap from the AMECO database operated by the European Commission. This gap is available at the yearly frequency and therefore, we used the gap in the specifications, where we use yearly data, too (e.g. the columns 1
} 
To compare with the results of Honohan and Lane (2003) presented in column (7), the effect of price convergence seems to be more important in the NMS than in the euro area countries. Our results for the NMS seem to be somewhat in contrast with evidence on the euro area countries such as the one provided by Hofmann and Remsperger (2005), as their results suggest that cyclical factors rather than real convergence matter for inflation differentials. To the contrary, our cyclical factors are often found to be insignificant.

Table 2 - The Determinants of Inflation Differentials, Panel GMM Estimates

\begin{tabular}{lccccccc}
\hline & $(1)$ & $(2)$ & $(3)$ & $(4)$ & $(5)$ & $(6)$ & $(7)$ \\
\hline Effective ex. rate & $-0.34^{* * *}$ & $-0.33^{* * *}$ & $-0.24^{* * *}$ & $-0.23^{* * *}$ & $-0.29^{* * *}$ & $-0.31^{* * *}$ & $-0.28^{* * *}$ \\
& $(0.10)$ & $(0.10)$ & $(0.02)$ & $(0.03)$ & $(0.02)$ & $(0.02)$ & $(0.08)$ \\
Output gap & 1.77 & 1.73 & $1.07^{*}$ & $1.23^{* *}$ & 0.26 & 0.99 & $0.23^{* * *}$ \\
& $(1.83)$ & $(1.74)$ & $(0.55)$ & $(0.61)$ & $(0.51)$ & $(0.51)$ & $(0.06)$ \\
Fiscal surplus & -0.13 & -0.16 & -0.11 & $-0.20^{*}$ & -0.08 & -0.07 & 0.07 \\
& $(0.14)$ & $(0.15)$ & $(0.08)$ & $(0.11)$ & $(0.07)$ & $(0.09)$ & $(0.04)$ \\
Price level & $-0.10^{* *}$ & $-0.10^{* *}$ & $-0.09^{* * *}$ & $-0.10^{* * *}$ & $-0.08^{* * *}$ & $-0.07^{* * *}$ & $-0.03^{* * *}$ \\
& $(0.04)$ & $(0.05)$ & $(0.02)$ & $(0.02)$ & $(0.01)$ & $(0.02)$ & $(0.01)$ \\
& & & & & & & \\
Adjusted R & & & & & & & \\
Sample period & 9.25 & 0.26 & 0.29 & 0.28 & 0.46 & 0.47 & 0.60 \\
\hline
\end{tabular}

Notes: The results in columns (1) - (2) are based on yearly data, columns (3)-(6) are based on quarterly data. Columns (1)-(4) assume that exchange rate and price level is lagged by one period, while (5)-(6) assume that they are lagged by four periods to shed light on the sensitivity of results. Column (7) presents original Honohan and Lane (2003, p. 375, Table 6, column 1) results for the euro area countries. Period fixed effects included. White diagonal standard errors with degrees of freedom correction and are in the brackets. *,**,*** denote significance at the 10, 5, and $1 \%$ levels, respectively. Constants not presented. Annual and quarterly frequency are denoted by A and Q, respectively.

Source: Author's calculations based on Eurostat data.

and 2 in Table 2 and 3). Similarly to the results that we present in these tables, this measure of output gap was found to be insignificant, too. 
Next, we exclude a country that exhibited highest inflation during our sample period (Romania). The results are relatively unchanged in terms of the significance of coefficients, but the size of estimated coefficients seems to change a bit. The results are available in Table 3. Notably, the effect of effective exchange rate appreciation and price level convergence seem to be a bit smaller (but still significant in all specifications, as in Table 2), and output gap and fiscal surplus become significant in more specifications. We think that the point estimates in Table 3 - that can be used for some simple policy analysis - are more trustful, as we exclude a clear outlier.

The point estimate around -0.2 indicate that $5 \%$ appreciation of exchange rate decreases inflation additionally by one percentage point. To compare, the Czech nominal effective exchange rate appreciated on average by $3.7 \%$ during 1997-2006. As in Table 2, positive output gap seem to increase inflation and the size of estimated coefficients varies a bit across the specifications. As regards the fiscal surplus, the point estimate in between -0.1 and -0.2 indicate that an increase in inflation differential of additional one percentage point is related to the fiscal deficit of about 5$10 \%$ of GDP. The point estimate of about -0.05 indicates that country with price level $20 \%$ below the euro area average is likely to exhibit inflation nearly one percentage point above the euro area. This is a plausible effect, when taking into account relative price level in the NMS, where our data show that average price level in the NMS in 2006 was about $60 \%$. In this regard, Mody and Ohnsorge (2007) find the effect of comparative price level on inflation in the NMS somewhat smaller around -0.02 . Overall, our results suggest that real convergence factors rather than cyclical variation are likely to be more important for the NMS, as compared to the euro area. 
Table 3 - The Determinants of Inflation Differentials:

Panel GMM Estimates, without Romania

\begin{tabular}{|c|c|c|c|c|c|c|}
\hline & (1) & (2) & (3) & (4) & (5) & (6) \\
\hline \multirow[t]{2}{*}{ Effective ex. rate } & $-0.21^{* * *}$ & $-0.20^{* * *}$ & $-0.20^{* * *}$ & $-0.19^{* * *}$ & $-0.21^{* * *}$ & $-0.20^{* * *}$ \\
\hline & $(0.05)$ & $(0.05)$ & $(0.02)$ & $(0.02)$ & $(0.03)$ & $(0.03)$ \\
\hline \multirow[t]{2}{*}{ Output gap } & 1.18 & 1.08 & $0.43^{* *}$ & $0.44^{* *}$ & $1.72^{* *}$ & $1.71^{* *}$ \\
\hline & $(1.01)$ & $(0.88)$ & $(0.20)$ & $(0.21)$ & $(0.77)$ & $(0.81)$ \\
\hline \multirow[t]{2}{*}{ Fiscal surplus } & -0.11 & -0.11 & $-0.10^{* *}$ & $-0.16^{* * *}$ & -0.07 & -0.08 \\
\hline & $(0.16)$ & $(0.17)$ & $(0.05)$ & $(0.06)$ & $(0.08)$ & $(0.09)$ \\
\hline \multirow[t]{2}{*}{ Price level } & $-0.06^{* *}$ & $-0.05^{*}$ & $-0.06^{* * *}$ & $-0.05^{* * *}$ & $-0.06^{* * *}$ & $-0.06^{* * *}$ \\
\hline & $(0.03)$ & $(0.03)$ & $(0.01)$ & $(0.01)$ & $(0.01)$ & $(0.01)$ \\
\hline No. of observations & 91 & 80 & 379 & 335 & 364 & 320 \\
\hline Data frequency & A & A & Q & Q & Q & Q \\
\hline Sample period & $97-06$ & $97-06$ & $97-06$ & $97-05$ & $97-06$ & $97-05$ \\
\hline Adjusted $\mathrm{R}^{2}$ & 0.29 & 0.24 & 0.39 & 0.39 & 0.15 & 0.15 \\
\hline
\end{tabular}

Notes: The results in columns (1) - (2) are based on yearly data, columns (3)-(6) are based on quarterly data. Columns (1)-(4) assume that exchange rate and price level is lagged by one period, while (5)-(6) assume that they are lagged by four periods to shed light on the sensitivity of results. Column (7) presents original Honohan and Lane (2003, p. 375, Table 6, column 1) results for the euro area countries. Period fixed effects included. White diagonal standard errors with degrees of freedom correction and are in the brackets. *,**, ** denote significance at the 10,5 , and $1 \%$ levels, respectively. Constants not presented. Annual and quarterly frequency are denoted by A and Q, respectively.

Source: Author's calculations based on Eurostat data.

\section{Concluding remarks}

In this paper, we investigate the driving factors for inflation differentials in the European Union New Member States (NMS) by means of panel data analysis in 1997-2006. Our main results are as follows. The nominal effective exchange rate appreciation in the NMS reduces the inflation differentials. Our point estimate around -0.2 suggests that about $5 \%$ appreciation of exchange rate decreases inflation by additional one percentage point. To compare, the Czech nominal effective exchange rate appreciated on average by 3.7\% during 1997-2006. Output gap is positively associated with inflation and fiscal surplus seem to decrease inflation. The point estimate of between -0.1 and -0.2 for fiscal surplus indicates that an increase in inflation 
differential of one percentage point would be related to the fiscal deficit of about 5-10\% of GDP. Countries with lower price level exhibit higher inflation. The point estimate of about -0.05 suggests that country with price level $20 \%$ below the euro area average is likely to exhibit inflation nearly one percentage point above the euro area. This is a plausible effect, when taking into account relative price level in the NMS, where our data indicate that average price level in the NMS in 2006 was about 60\%. Comparing our results to Honohan and Lane (2003) for the euro area that use analogous empirical approach, we find that albeit the set of inflation differentials determinants is largely comparable, the effect of price level seems to be more important in the NMS than in the euro area. More generally, our results indicate that real convergence factors rather than cyclical variation are likely to be more important for inflation developments in the new EU members, as compared to the euro area.

In terms of future research, we believe that it would be worthwhile to build carefully calibrated general equilibrium models simulating the inflation developments in the NMSs after euro adoption. This is important, as the results based on regression analysis are typically not immune to the Lucas critique and therefore only shed light on potential developments of inflation differentials after joining monetary union. More specifically, it would be especially interesting both for academic circles and policy makers to obtain the relative contribution of exchange rate channel in curbing inflation in these countries. 


\section{References}

Altissimo, F., Benigno, P. and Palenzuela, D., R. (2005) Long-run Determinants of Inflation Differentials in a Monetary Union, CEPR Discussion Papers, No. 5149.

Angeloni, I. and Ehrmann, M. (2007) Euro Area Inflation Differentials, Topics in Macroeconomics, 7(1), Article 24.

Čihák, M. and Holub, T. (2005) Price Convergence in EU Accession Countries: Evidence from the International Comparison, Économie Internationale 2/2005, No. 102, 59-82.

Égert, B., Ritzberger-Grunwald, D., and Silgoner, M.A. (2003) Inflation Differentials in Europe: Past Experience and Future Prospects, Focus on Transition, Vol. 2, Oesterreichische Nationalbank, 47-72.

Égert, B., Halpern, L. and MacDonald, R. (2006) Equilibrium Exchange Rates in Transition Economies: Taking Stock of the Issues, Journal of Economic Surveys, 20(2), 257-324.

Égert, B., (2007) Real Convergence, Price Level Convergence and Inflation Differentials in Europe, William Davidson Institute Working Paper, No. 895.

Égert, B. (2008) Prices and Price Convergence in Emerging Europe: An Overview, National Institute Economic Review, 66-84.

European Central Bank (1999) Inflation Differentials in a Monetary Union, European Central Bank Monthly Bulletin, October 1999: 37-47.

European Central Bank (2003) Inflation Differentials in the Euro Area: Potential Causes and Policy Implications.

Fendel, R. and Frenkel, M. (2008) Inflation Differentials in the Euro Area: Did the ECB Care? Applied Economics, forthcoming.

Fidrmuc, J. and Korhonen, I. (2006) Meta-analysis of the Business Cycle Correlation between the Euro Area and the CEECs, Journal of Comparative Economics, 34(3), 518-537.

Hofmann, B., Remsperger, H. (2005) Inflation Differentials among the Euro Area Countries: Potential Causes and Consequences, Journal of Asian Economics, 16(3), 403-419.

Honohan, P. and Lane, P. (2003) Divergent Inflation Rates in EMU, Economic Policy, 358-394.

Mody, A. and F. Ohnsorge (2007) Can Domestic Policies Influence Inflation?, International Monetary Fund Working Paper, No. 257/07.

Stavrev, E. (2006) Driving Forces of Inflation in New EU8 Countries, Finance a wivèr - Czech Journal of Economics and Finance, 246-257. 


\section{DAVIDSON INSTITUTE WORKING PAPER SERIES - Most Recent Papers}

The entire Working Paper Series may be downloaded free of charge at: www.wdi.umich.edu

CURRENT AS OF 10/9/08

\begin{tabular}{|c|c|c|}
\hline Publication & Authors & Date \\
\hline $\begin{array}{l}\text { No. 937: Inflation Differentials in EU New Member States: An Empirical } \\
\text { Evidence }\end{array}$ & Roman Horvath \& Kamila Koprnicka & Oct 2008 \\
\hline $\begin{array}{l}\text { No. 936: Market Reforms and Growth in Post-socialist Economies: } \\
\text { Evidence from Panel Cointegration and Equilibrium Correction Model }\end{array}$ & Igor Pelipas and Alexander Chubrik & Sept 2008 \\
\hline $\begin{array}{l}\text { No. 935: Derivatives trading and the volume-volatility link in the Indian } \\
\text { Stock Market }\end{array}$ & $\begin{array}{l}\text { S. Bhaumiky, M. Karanasosy and } \\
\text { A. Kartsaklas }\end{array}$ & April 2008 \\
\hline $\begin{array}{l}\text { No. 934: Yuan Real Exchange Rate Undervaluation, 1997-2006. How } \\
\text { Much, How Often? Not Much, Not Often }\end{array}$ & $\begin{array}{l}\text { Jeff Chen, Wende Deng \& David } \\
\text { Kemme }\end{array}$ & Aug 2008 \\
\hline $\begin{array}{l}\text { No. 933: How Important Are Foreign Shocks in Small Open Economy? } \\
\text { The Case of Slovakia }\end{array}$ & $\begin{array}{l}\text { Roman Horváth and Marek } \\
\text { Rusnák }\end{array}$ & Sept 2008 \\
\hline $\begin{array}{l}\text { No. 932: Estimating Poverty for Indigenous Groups in Chile } \\
\text { by Matching Census and Survey Data }\end{array}$ & $\begin{array}{l}\text { Claudio A. Agostini, Philip H. } \\
\text { Brown, and Andrei Roman }\end{array}$ & Aug 2008 \\
\hline $\begin{array}{l}\text { No. 931: Is There Electoral Cycles In Globalization Process? Evidence } \\
\text { From } 78 \text { Democratic Countries, } 1975 \text { - } 2006\end{array}$ & Krishna Chaitanya Vadlamannati & Sept 2008 \\
\hline No. 930: Lobbying, Corruption \& Other Banes & $\begin{array}{l}\text { Nauro Campos \& Francesco } \\
\text { Giovannoni }\end{array}$ & Sept 2008 \\
\hline $\begin{array}{l}\text { No. 929: Do Elections Slow Down Economic Globalization Process In } \\
\text { India? It's Politics Stupid! }\end{array}$ & Krishna C Vadlamannati & Aug 2008 \\
\hline $\begin{array}{l}\text { No. 928: Impact Of Institutional Quality On Human Rights Abuses } \\
\text { In Transition Economies }\end{array}$ & $\begin{array}{l}\text { Krishna C Vadlamannati \& Artur } \\
\text { Tamazian }\end{array}$ & July 2008 \\
\hline $\begin{array}{l}\text { No. 927: Do Choice \& Speed Of Reforms Matter For } \\
\text { Human Rights During Transition? }\end{array}$ & Krishna Chaitanya Vadlamannati & July 2008 \\
\hline $\begin{array}{l}\text { No. 926: Socioeconomic, Institutional \& Political Determinants Of } \\
\text { Human Rights Abuses: A Subnational Study Of India, } 1993 \text { - } 2002\end{array}$ & Krishna Chaitanya Vadlamannati & July 2008 \\
\hline $\begin{array}{l}\text { No. 925: Does the Entry Mode of Foreign Banks Matter for Bank } \\
\text { Efficiency? Evidence from the Czech Republic, Hungary, and } \\
\text { Poland }\end{array}$ & $\begin{array}{l}\text { Ngoc-Anh Vo Thi \& Dev } \\
\text { Vencappa }\end{array}$ & July 2008 \\
\hline No. 924: Impact Of Economic Reforms On Poverty - Indian Experience & Krishna Chaitanya Vadlamannati & July 2008 \\
\hline $\begin{array}{l}\text { No. 923: India \& South Asia - Indian Economic Reforms \& Direct } \\
\text { Foreign Investments: How Much Difference Do They Make To } \\
\text { Neighbors? }\end{array}$ & Krishna Chaitanya Vadlamannati & July 2008 \\
\hline $\begin{array}{l}\text { No. 922: The Effects of Monetary Policy in the Czech Republic: } \\
\text { An Empirical Study }\end{array}$ & $\begin{array}{l}\text { Magdalena Morgese Borys and } \\
\text { Roman Horváth }\end{array}$ & May 2008 \\
\hline $\begin{array}{l}\text { No. 921: Goods Market Integration in Russia during the Economic } \\
\text { Upturn }\end{array}$ & Konstantin Gluschenko & May 2008 \\
\hline $\begin{array}{l}\text { No. 920: Labour Market Matching Efficiency In The Czech Republic } \\
\text { Transition }\end{array}$ & Pablo de Pedraza & April 2008 \\
\hline $\begin{array}{l}\text { No. 919: The Emerging Aversion to Inequality: Evidence from Poland } \\
\text { 1992-2005 }\end{array}$ & Irena Grosfeld and Claudia Senik & April 2008 \\
\hline $\begin{array}{l}\text { No. 918: Exploring The Relationship Between Military Spending \& } \\
\text { Income Inequality In South Asia }\end{array}$ & Krishna Chaitanya Vadlamannati & Feb 2008 \\
\hline $\begin{array}{l}\text { No. 917: Productive, Unproductive and Destructive Entrepreneurship: A } \\
\text { Theoretical and Empirical Exploration }\end{array}$ & Arnis Sauka & Mar 2008 \\
\hline $\begin{array}{l}\text { No. 916: MARKET RISK DYNAMICS AND COMPETITIVENESS } \\
\text { AFTER THE EURO: Evidence from EMU Members }\end{array}$ & $\begin{array}{l}\text { Juan Piñeiro Chousa, Artur } \\
\text { Tamazian \& Davit N. Melikyan }\end{array}$ & Feb 2008 \\
\hline No. 915: An Impact Analysis of Microfinance in Bosnia and Herzegovina & $\begin{array}{l}\text { Valentina Hartarska \& Denis } \\
\text { Nadolnyak }\end{array}$ & Dec 2007 \\
\hline
\end{tabular}

